Пішковці А.-М.М.

\title{
Результати соціологічного опитування батьків щодо збереження стоматологічного здоров'я дітей
}

\author{
ДВНЗ «Ужгородський національний університет», м. Ужгород, Україна
}

annamariaremez@gmail.com

Пишковци А.-М.M.

Результаты социологического опроса родителей по сохранению стоматологического здоровья детей

ГВУЗ «Ужгородский национальный университет», г. Ужгород, Украина
Pishkovtsi A.-M.M

Results of sociological research of parents on maintenance of children's teeth health Uzhhorod National University, Uzhhorod, Ukraine

\section{Вступ}

В Україні відмічається незадовільний стан стоматологічного здоров'я у дитячого населення який має тенденцію до погіршення $[1,2]$. Незадовільний показники стоматологічного здоров'я у дітей реєструються i в Закарпатській області $[3,4]$. При цьому необхідно зазначити, що в покращенні показників стоматологічного здоров'я дітей важливе значення мають комплексні профілактичні заходи [5,6] якість та ефективність яких залежать в тому числі від рівня поінформованості населення про них та мотивованості до здійснення профілактичних заходів [7].

Мета роботи: дослідити діяльність батьків Закарпатської області по збереженню стоматологічного здоров'я дітей.

\section{Матеріали та методи}

В ході дослідження використано наступні методи дослідження: соціологічний, статистичний, структурнологічного аналізу. Матеріалами дослідження слугували результати проведеного за спеціально розробленою анкетою серед батьків дітей, що навчаються в загальноосвітніх школах соціологічного дослідження. Дослідженням охоплено 400 батьків дітей, які проживають в Закарпатській області. Дані про респондентів наведено в табл. 1. В ході дослідження збережено конфіденційність даних про респондентів. Участь у дослідженні була добровільною.

Із числа респондентів $41,8 \%$ були сільськими жителями та 58,2\% - жителями міст, $48,0 \%$ респондентів були батьками дітей, а 52,0\% - матеріями. Із числа дітей $47,3 \%$ були хлопчиками, а 52,7\% - дівчатками при цьому вік дітей становив від 6 до 17 років життя.
Таблиця 1. Дані про респондентів - батьків, що прийняли участь у досліджені

\begin{tabular}{|c|c|c|}
\hline Показник & Абс. & $\%$ \\
\hline \multicolumn{3}{|c|}{ Місцевість проживання } \\
\hline Сільська місцевість & 163 & 41,8 \\
\hline Місто & 237 & 58,2 \\
\hline \multicolumn{3}{|c|}{ Рівень родинного зв'язу } \\
\hline Батько & 192 & 48,0 \\
\hline Мати & 208 & 52,0 \\
\hline \multicolumn{3}{|c|}{ Вік дітей } \\
\hline 6-7 років & 85 & 21,3 \\
\hline 8-10 років & 94 & 23,5 \\
\hline 11-12 років & 102 & 25,5 \\
\hline 13-14 років & 76 & 19,0 \\
\hline 15-17 років & 43 & 10,7 \\
\hline \multicolumn{3}{|c|}{ Стать дітей } \\
\hline Хлопчик & 189 & 47,3 \\
\hline Дівчинка & 211 & 52,7 \\
\hline
\end{tabular}

Результати дослідження та їх обговорення

На першому етапі дослідження було вивчено соціально-економічний статус сім'ї із яких опитано батьків дітей-школярів. Отримані дані наведено в табл. 2.

Аналіз наведених в табл. 2 даних вказує на те, що із числа опитаних $12,3 \pm 1,6 \%$ сімей живуть в повному достатку, а у $43,4 \pm 2,5 \%$ сімей грошей достатньо на саме необхідне при цьому у $7,8 \pm 1,3 \%$ сімей грошей не достатньо на саме необхідне.

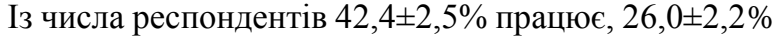
є приватними підприємцями, $20,3 \pm 2,0 \%$ - службовцями та $11,3 \pm 1,6 \%$ є безробітними.

Рівень освіти опитаних батьків коливається від неповної середньої до вищої. При цьому рівень освіти 
опитаних матерів є вищим ніж рівень освіти опитаних батьків.

Далі було вивчено питання наближеності до місця проживання кабінету лікаря-стоматолога. Респонденти вказали на наближеність стоматологічного кабінету до місце проживання у $55,6 \pm 2,5 \%$ (як правило респонденти, що проживають в містах) та 44,4 $2,5 \%$ на віддаленість від місця проживання кабінету лікаря-стоматолога.

Наступним кроком дослідження було вивчення питання щодо джерел отримання батьками інформації щодо збереження стоматологічного здоров'я дітей. Отримані результати наведено на рисунку.

\section{Таблиця 2. Соціально-економічний статус сім'ї}

\begin{tabular}{|c|c|c|c|}
\hline \multicolumn{2}{|l|}{ Показник } & Абс. & $\%$ \\
\hline \multicolumn{4}{|c|}{ Економічний рівень сім’ї } \\
\hline \multicolumn{2}{|l|}{ Сім’я проживає в повному достатку } & 49 & $12,3 \pm 1,6$ \\
\hline \multicolumn{2}{|l|}{ Грошей достатньо на все необхідне } & 146 & $36,5 \pm 2,4$ \\
\hline \multicolumn{2}{|l|}{ Грошей достатньо на саме необхідне } & 174 & $43,4 \pm 2,5$ \\
\hline \multicolumn{2}{|c|}{ Грошей не достатньо на саме необхідне } & 31 & $7,8 \pm 1,3$ \\
\hline \multicolumn{4}{|c|}{ Рівень соціального статусу (за респондентом) } \\
\hline \multicolumn{2}{|l|}{ Працює } & 170 & $42,4 \pm 2,5$ \\
\hline \multicolumn{2}{|l|}{ Приватний підприємець } & 104 & $26,0 \pm 2,2$ \\
\hline \multicolumn{2}{|l|}{ Службовець } & 81 & $20,3 \pm 2,0$ \\
\hline \multicolumn{2}{|l|}{ Безробітний } & 45 & $11,3 \pm 1,6$ \\
\hline \multicolumn{4}{|c|}{ Рівень освіти батьків } \\
\hline \multirow[t]{2}{*}{ Вища } & батько & 32 & $16,7 \pm 1,8$ \\
\hline & мати & 53 & $25,5 \pm 2,2$ \\
\hline \multirow[t]{2}{*}{ Не закінчена вища } & батько & 14 & $7,3 \pm 1,3$ \\
\hline & мати & 21 & $10,1 \pm 1,5$ \\
\hline \multirow[t]{2}{*}{ Середня спеціальна } & батько & 59 & $30,7 \pm 2,3$ \\
\hline & мати & 41 & $19,7 \pm 2,0$ \\
\hline \multirow[t]{2}{*}{ Середня } & батько & 53 & $27,6 \pm 2,2$ \\
\hline & мати & 66 & $31,7 \pm 2,3$ \\
\hline \multirow[t]{2}{*}{ Неповна середня } & батько & 34 & $17,7 \pm 1,9$ \\
\hline & мати & 27 & $13,0 \pm 1,7$ \\
\hline
\end{tabular}

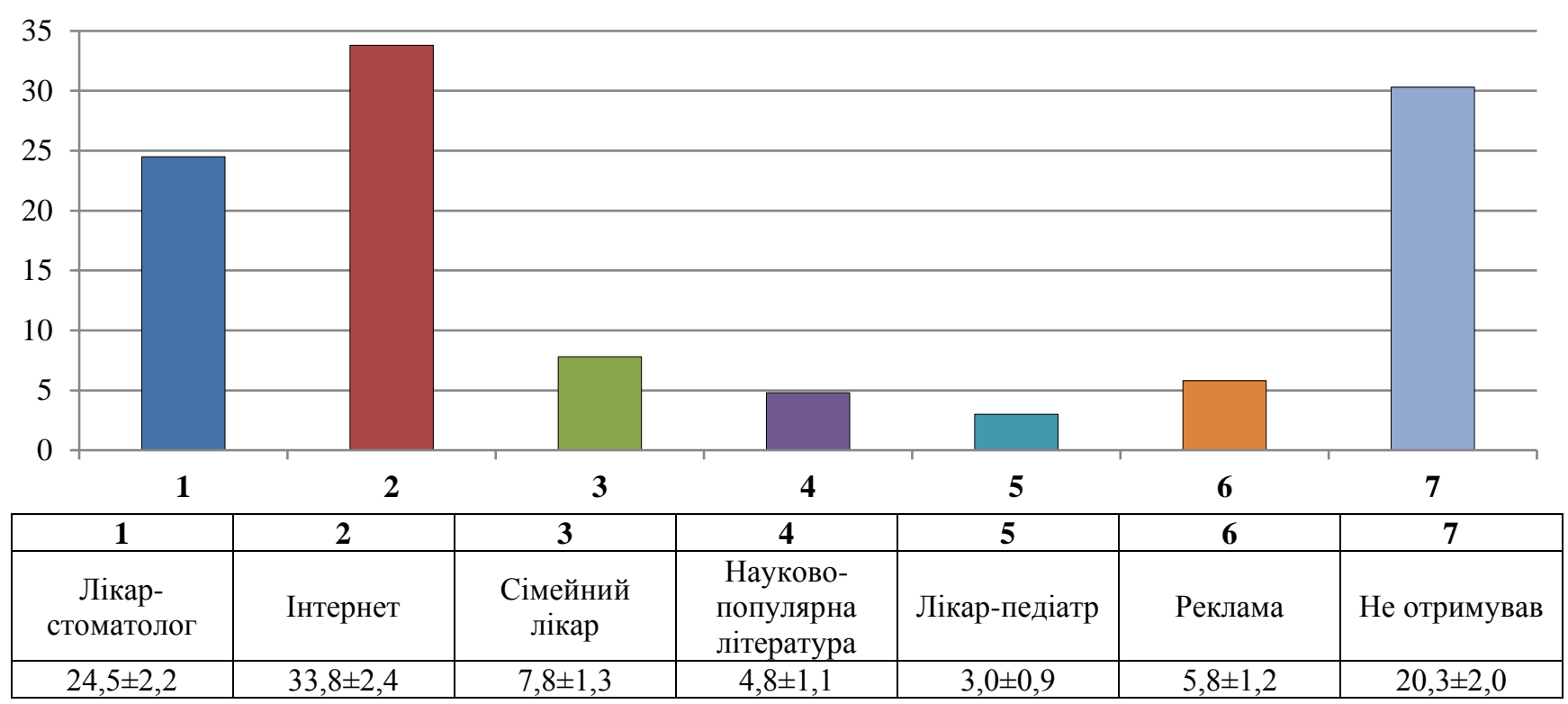

Рис. Джерела отримання інформації батьками з питань збереження стоматологічного здоров’я дітей, \% 
Аналіз наведених на рисунку результатів опитування вказує на те, що основними джерелами отримання інформації щодо збереження стоматологічного здоров’я дітей для батьків $є$ консультації надані лікарем стоматологом $(24,5 \pm 2,2 \%)$ та інтернет ресурс $(33,8 \pm 2,4 \%)$. При цьому 20,3 2 2,0\% респондентів інформацію 3 питань збереження стоматологічного здоров'я дітей не отримували.

Результати дослідження з питань звернення дитини до сімейних лікарів для отримання профілактичної допомоги наведені в табл. 3.

Наведені в табл. 3 дані вказують на те, що із загальної кількості респондентів до сімейних лікарів 3 метою отримання профілактичної допомоги дітям зверталося $69,3 \pm 2,4 \%$ із них. При цьому сімейний лікар оглядав порожнину рота дитини у $55,6 \pm 2,5 \%$ випадків звернення і тільки у 6,9土1,3\% сімейний лікар надавав рекомендації по догляду за порожниною рота.

В ході дослідження також було встановлено, що $74,3 \pm 2,2 \%$ дітей оглядаються 3 профілактичною метою лікарем-стоматологом в навчальному закладі, де вони навчаються.

В табл. 4 наведені результати соціологічного дослідження щодо звернення дитини до лікарівстоматологів для отримання профілактичної стоматологічної допомоги.

\section{Таблиця 3. Звернення дитини до сімейних лікарів для отримання профілактичної допомоги}

\begin{tabular}{|l|c|c|}
\hline \multicolumn{1}{|c|}{ Показник } & Абс. & \multicolumn{1}{c|}{ \% } \\
\hline Звертаються & 277 & $69,3 \pm 2,4$ \\
\hline Не звертаються & 123 & $30,7 \pm 2.3$ \\
\hline Сімейний лікар оглядав порожнину рота дитини & 154 & $55,6 \pm 2,5$ \\
\hline Сімейний лікар скеровував він дитину до лікаря-стоматолога & 12 & $4,3 \pm 1,0$ \\
\hline Сімейний лікар надавав рекомендації по догляду за порожниною рота & 19 & $6,9 \pm 1,3$ \\
\hline $\begin{array}{l}\text { Проводяться профілактичні огляди порожнини рота (стоматологічні) в навчальному } \\
\text { закладі, де навчається дитина }\end{array}$ & 297 \\
\hline
\end{tabular}

Таблиця 4. Звернення дитини до лікарів-стоматологів для отримання профілактичної стоматологічної допомоги

\begin{tabular}{|c|}
\hline Показник \\
\hline Дитина відвідує лікаря-стоматолога із профілактичною м \\
\hline 1 раз на рік \\
\hline 2 рази на рік \\
\hline 3 рази на рік \\
\hline Відвідує лікаря-стоматолога з оплатою батьками \\
\hline Відвідує лікаря-стоматолога безоплатно \\
\hline $\begin{array}{l}\text { Завжди виконуються поради лікаря-стоматолога по збере } \\
\text { здоров’я дитини }\end{array}$ \\
\hline При необхідності проводиться дитині санація порожнини \\
\hline Не проводиться із за відсутності коштів \\
\hline Не проводиться із за відсутності часу \\
\hline Не проводиться із за відсутності в населеному пункті лік \\
\hline 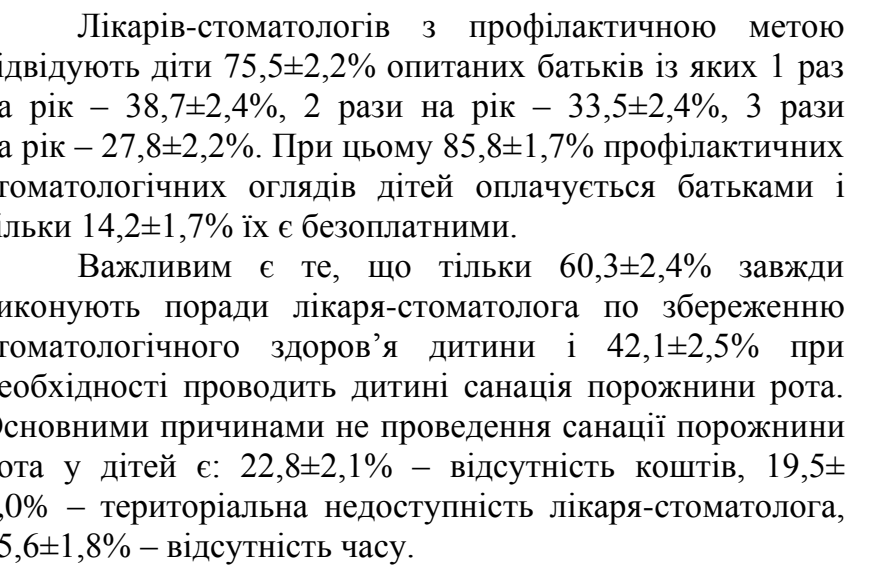 \\
\hline
\end{tabular}

\begin{tabular}{|c|c|}
\hline Абс. & $\%$ \\
\hline 302 & $75,5 \pm 2,2$ \\
\hline 117 & $38,7 \pm 2,4$ \\
\hline 101 & $33,5 \pm 2,4$ \\
\hline 84 & $27,8 \pm 2,2$ \\
\hline 259 & $85,8 \pm 1,7$ \\
\hline 43 & $14,2 \pm 1,7$ \\
\hline & \\
\hline 182 & $60,3 \pm 2,4$ \\
\hline 127 & $42,1 \pm 2,5$ \\
\hline 69 & $22,8 \pm 2,1$ \\
\hline 47 & $15,6 \pm 1,8$ \\
\hline 59 & $19,5 \pm 2,0$ \\
\hline
\end{tabular}

Нами також було вивчено питання догляду дитиною за порожниною рота. Отримані результати наведено в табл. 5 .

В ході дослідження встановлено, що всі діти числять зуби при цьому $54,3 \pm 2,5 \%$ один раз на день та $45,7 \pm 2,5 \%$ два рази на день в тому числі $55,3 \pm 2,5 \%$ до вживання їжі та 44,7 $22,5 \%$ після вживання їжі тривалістю від однієї хвилини $(38,0 \pm 2,4 \%)$ до трьох хвилин $(23,0 \pm 2,1 \%)$.

Зубну щітку, яку батьки вибирали на свій розсуд $(97,0 \pm 0,9 \%)$, змінюють регулярно: кожні три місяці $(38,8 \pm 2,4 \%), \quad$ кожні півроку $(49,0 \pm 2,5 \%)$ та рідше $(12,2 \pm 1,6 \%)$. Тільки $3,0 \pm 0,9 \%$ дітей навчав чистити зуби лікар-стоматолог, решту - батьки. В ході дослідження 
також встановлено, що 12,3土1,6\% дітей завжди проводить полоскання порожнини рота після прийому їжі, 3,0土 0,9\% - після вживання солодощів та $6,8 \pm 1,3 \%$ перед сном.
Також було вивчено питання щодо рівня бажання батьків отримувати інформацію про забезпечення здоров'я порожнини рота у дітей та найзручніші способи отримання ними інформації. Результати наведено в табл. 6.

\section{Таблиця 5. Догляд дитиною за порожниною рота}

\begin{tabular}{|c|c|c|c|}
\hline \multicolumn{2}{|l|}{ Показник } & Абс. & $\%$ \\
\hline \multicolumn{2}{|l|}{ Дитина чистить зуби 1 раз на день } & 217 & $54,3 \pm 2,5$ \\
\hline \multicolumn{2}{|l|}{ Дитина чистить зуби 2 рази на день } & 183 & $45,7 \pm 2,5$ \\
\hline \multicolumn{2}{|l|}{ Дитина чистить зуби до вживання їжі } & 221 & $55,3 \pm 2,5$ \\
\hline \multicolumn{2}{|l|}{ Дитина чистить зуби після вживання їжі } & 179 & $44,7 \pm 2,5$ \\
\hline \multirow[t]{3}{*}{ Тривалість чищення зубів } & 1 хвилина & 152 & $38,0 \pm 2,4$ \\
\hline & 2 хвилини & 156 & $39,0 \pm 2,4$ \\
\hline & 3 хвилини & 92 & $23,0 \pm 2,1$ \\
\hline \multirow[t]{3}{*}{ Частота зміни зубної щітки } & Кожні 3 місяці & 155 & $38,8 \pm 2,4$ \\
\hline & Кожні 6 місяців & 196 & $49,0 \pm 2,5$ \\
\hline & Рідше & 49 & $12,2 \pm 1,6$ \\
\hline \multirow[t]{3}{*}{ Навчив дитину чистити зуби } & Мати & 215 & $53,7 \pm 2,5$ \\
\hline & Батько & 173 & $43,3 \pm 2,5$ \\
\hline & Лікар-стоматолог & 12 & $3,0 \pm 0,9$ \\
\hline \multirow[t]{2}{*}{ Рекомендував вибір зубної пасти } & Медичний працівник & 12 & $3,0 \pm 0,9$ \\
\hline & Вибирали батьки & 388 & $97,0 \pm 0,9$ \\
\hline \multirow[t]{2}{*}{ Рекомендував вибір зубної щітки } & Медичний працівник & 12 & $3,0 \pm 0,9$ \\
\hline & Вибирали батьки & 388 & $97,0 \pm 0,9$ \\
\hline \multicolumn{2}{|c|}{ Дитина використовує додаткові засоби гігієни порожнини рота } & 159 & $39,8 \pm 2,4$ \\
\hline \multirow{3}{*}{$\begin{array}{l}\text { Дитина проводить полоскання порожнини рота } \\
\text { після прийому їжі }\end{array}$} & Завжди & 49 & $12,3 \pm 1,6$ \\
\hline & Інколи & 275 & $68,7 \pm 2,3$ \\
\hline & Ніколи & 76 & $19,0 \pm 2,0$ \\
\hline \multirow{3}{*}{$\begin{array}{l}\text { Дитина проводить полоскання порожнини рота } \\
\text { після вживання солодощів }\end{array}$} & Завжди & 12 & $3,0 \pm 0,9$ \\
\hline & Інколи & 289 & $72,2 \pm 2,2$ \\
\hline & Ніколи & 99 & $24,8 \pm 2,2$ \\
\hline \multirow{3}{*}{$\begin{array}{l}\text { Дитина проводить полоскання порожнини рота } \\
\text { перед сном }\end{array}$} & Завжди & 27 & $6,8 \pm 1,3$ \\
\hline & Інколи & 267 & $66,7 \pm 2,4$ \\
\hline & Ніколи & 106 & $26,5 \pm 2,2$ \\
\hline
\end{tabular}

Таблиця 6. Бажання батьків отримувати інформацію про забезпечення здоров'я порожнини рота у дітей та найзручніший спосіб отримання інформації

\begin{tabular}{|c|c|c|}
\hline Показник & Абс. & $\%$ \\
\hline Бажає & 339 & $84,8 \pm 1,8$ \\
\hline Не бажає & 37 & $9,3 \pm 1,4$ \\
\hline Не визначився & 24 & $5,9 \pm 1,2$ \\
\hline \multicolumn{3}{|c|}{ Найзручніший спосіб отримання інформації $(\mathrm{n}=339)$} \\
\hline Проведення практичного заняття лікарем для дітей і батьків & 41 & $12,1 \pm 1,6$ \\
\hline Індивідуальна консультація медичного працівника & 193 & $56,9 \pm 2,5$ \\
\hline Отримання методичних рекомендацій & 17 & $5,0 \pm 1,1$ \\
\hline Отримання рекомендацій із спеціального інтернет- сайту & 88 & $26,0 \pm 2,2$ \\
\hline
\end{tabular}

В ході дослідження було встановлено, що $84,8 \pm 1,8 \%$ опитаних батьків мають бажання отримувати інформацію про можливі шляхи забезпечення здоров'я порожнини рота у дітей. При цьому респонденти найбільш зручними способами отримання інформації назвали індивідуальні консультації медичного працівника 
$(56,9 \pm 2,5 \%)$ та отримання рекомендацій із спеціального інтернет-сайту $(26,0 \pm 2,2 \%)$.

Перспективи подальших досліджень пов'язані 3 вивченням показників стоматологічного здоров'я дитячого населення Закарпаття в залежності від географічної зони проживання.

\section{Висновки}

В ході дослідження встановлено, що батьки недостатнь уваги приділяють збереженню стоматологічного здоров'я дітей в тому числі проходженню профілактичних оглядів та проведенню санації порожнини рота. Ці послуги, як правило $є$ платними. Також батьки, в своїй більшості, не поінформовані від медичних працівників про профілактичні заходи по збереженню стоматологічного здоров’я дітей, але бажають мати необхідну інформацію.

Результати дослідження мають бути використані при розробці профілактичних заходів лікарів первинної ланки та системи громадського здоров'я.

\section{Література}

1. Бауман С.С. Порівняльна оцінка ураженості карієсом зубів дітей м. Полтави / С.С. Бауман, К.В.Турчіна, А.С. Мосієнко та інш. // Вісник проблем біології та медицини. 2017. Вип. №3, т. 2. С. 165-167/

2. Назарян Р.С. Заболеваемость кариесом зубов у детей 8-9 лет г. Харькова / Р.С. Назарян, Н.Н. Удовиченко, К.Ю. Спиридонова // Український стоматологічний альманах. - 2013. - № 3. - С. 96-98.

3. Мельник Л.Ф. Моніторинг стоматологічного здоров’я дітей та підлітків Закарпатської області. / Л.Ф. Мельник, В.В. Горзов // «Науковий вісник Ужгородського університету» серія «Медицина». - 2018. - № 2(58). - С.96-99.

4. Казакова Р.В. Рівень стоматологічної захворюваності у підлітків м. Ужгород / Р.В. Казакова, В.С. Мельник, Л.Ф. Булей // Вісник стоматології. - 2012. - № 4. - С. 103-105.

5. Ляхова Н.О. Профілактика стоматологічних захворювань серед дитячого та дорослого населення України в практиці сімейного лікаря / Н.О. Ляхова, В.Л. Філатова, І.А. Голованова // Україна. Здоров’я нації. - 2016. № 1-2 (37-38).

6. Влияние стоматологической профилактической программы на качество жизни детей 3-10-летнего возраста / Л.П. Кисельникова, К.Г. Гуревич, М.М. Нагоева, Т.Е. Зуева // Стоматология для всех. - 2011. - № 4. - С. $52-55$.

7. Мочалов Ю.О. Порівняльна характеристика рівня знань щодо гігієни порожнини рота у різних вікових груп у м. Ужгород: соціологічне дослідження/ Ю.О. Мочалов, Г.М. Розлуцька // Проблеми клінічної педіатрії. - 2016. № 3-4. - C. 59-66.

\section{References}

1. Bauman S.S., Turchina K.V., Mosiyenko A.S. ta insh. (2017) Porivnyal'na otsinka urazhenosti kariyesom zubiv ditey m. Poltavy [Comparative assessment of dental caries in children of Poltava].Visnyk problem biolohiyi ta medytsyny, vol. 3, t. 2, pp. $165-167$

2. Nazaryan R.S., Udovichenko N.N., Spiridonova K.Yu. (2013) Zabolevaemost kariesom zubov u detej 8-9 let g. Harkova [The incidence of dental caries in children 8-9 years of Kharkov]. Ukrayinskij stomatologichnij almanah, vol. 3, pp. 96-98.

3. Mel'nyk L.F., Horzov V.V. (2018) Monitorynh stomatolohichnoho zdorov"ya ditey ta pidlitkiv Zakarpat·s'koyi oblasti[Monitoring the dental health of children and adolescents in the Transcarpathian region]. Naukovyy visnyk Uzhhorods'koho universytetu seriya «Medytsyna» - vol. 2(58), pp. 96-99.

4. Kazakova R.V., Mel'nyk V.S., Buley L.F. (2012) Riven' stomatolohichnoyi zakhvoryuvanosti u pidlitkiv m. Uzhhorod [The level of dental morbidity in adolescents in Uzhgorod]. Visnyk stomatolohiyi, vol. 4, pp. 103-105.

5. Lyakhova N.O., Filatova V.L., Holovanova I.A. (2016) Profilaktyka stomatolohichnykh zakhvoryuvan' sered dytyachoho ta dorosloho naselennya Ukrayiny v praktytsi simeynoho likarya [Prevention of dental diseases among children and adults in Ukraine in the practice of a family doctor]. Ukrayina. Zdorov"ya natsiyi, vol. 1-2, pp. 37-38.

6. Kisel`nikova L.P., Gurevich K.G., Nagoeva M.M., Zueva T.E. (2011) Vliyanie stomatologicheskoj profilakticheskoj programmy` na kachestvo zhizni detej 3-10-letnego vozrasta [Impact of a dental preventive program on the quality of life of children aged 3-10 years]. Stomatologiya dlya vsekh, vol. 4, pp. 52-55.

7. Mochalov Yu.O., Rozluts'ka H.M. (2016) Porivnyal'na kharakterystyka rivnya znan' shchodo hihiyeny porozhnyny rota $\mathrm{u}$ riznykh vikovykh hrup $\mathrm{u} \mathrm{m}$. Uzhhorod: sotsiolohichne doslidzhennya [Comparative characteristics of the level of knowledge about oral hygiene in different age groups in Uzhgorod: a sociological study]. Problemy klinichnoyi pediatriyi, vol. 3-4, pp. 59-66. 
Мета - дослідити діяльність батьків Закарпатської області по збереженню стоматологічного здоров’я дітей.

Матеріали та методи. В ході дослідження використано наступні методи дослідження: соціологічний, статистичний, структурно-логічного аналізу. Матеріалами дослідження слугували результати проведеного за спеціально розробленою анкетою серед батьків дітей, що навчаються в загальноосвітніх школах соціологічного дослідження. Дослідженням охоплено 400 батьків дітей, які проживають в Закарпатській області. В ході дослідження збережено конфіденційність даних про респондентів. Участь у дослідженні була добровільною.

Результати. В ході дослідження встановлено, що батьки недостатньо уваги приділяють збереженню стоматологічного здоров'я дітей в тому числі проходженню профілактичних оглядів та проведенню санації порожнини рота. Ці послуги, як правило є платними. Також батьки, в своїй більшості, не поінформовані від медичних працівників про профілактичні заходи по збереженню стоматологічного здоров'я дітей, але бажають мати необхідну інформацію.

Висновки. Результати дослідження мають бути використані при розробці профілактичних заходів лікарів первинної ланки та системи громадського здоров'я.

Ключові слова: батьки, діти, стоматологічне здоров’я, профілактика, забезпечення. детей.

Цель - исследовать деятельность родителей Закарпатской области по сохранению стоматологического здоровья

Материалы и методы. В ходе исследования использованы следующие методы исследования: социологический, статистический, структурно-логического анализа. Материалами исследования послужили результаты проведенного по специально разработанной анкете среди родителей детей, обучающихся в общеобразовательных школах социологического исследования. Исследованием охвачено 400 родителей детей, проживающих в Закарпатской области. В ходе исследования сохранено конфиденциальность данных о респондентов. Участие в исследовании было добровольным.

Результаты и их обсуждение. В ходе исследования установлено, что родители недостаточно внимания уделяют сохранению стоматологического здоровья детей в том числе прохождению профилактических осмотров и проведению санации полости рта. Эти услуги, как правило, являются платными. Также родители, в большинстве, не информированы от медицинских работников о профилактических мерах по сохранению стоматологического здоровья детей, но хотят иметь необходимую информацию.

Выводы. Результаты исследования должны быть использованы при разработке профилактических мероприятий врачей первичного звена и системы общественного здоровья.

Ключевые слова: родители, дети, стоматологическое здоровье, профилактика, обеспечение.

Purpose - to study the activities of parents in the Transcarpathian region to preserve the dental health of children.

Materials and methods. The following research methods were used during the research: sociological, statistical, structural-logical analysis. The materials of the study were the results of a sociological survey conducted on a specially designed questionnaire among parents of children enrolled in secondary schools. The study covered 400 parents of children living in the Transcarpathian region. During the study, the confidentiality of data on respondents was maintained. Participation in the study was voluntary.

Results. Research has shown that parents do not pay enough attention to maintaining their children's dental health, including preventive examinations and oral rehabilitation. These services are usually paid. In addition, most parents do not inform health professionals about preventive measures to maintain the health of children's teeth, but want to have the necessary information.

Conclusions. The results of the study should be used in the development of preventive measures for primary care physicians and the public health system.

Key words: parents, children, dental health, prevention, provision.

\section{Відомості про автора}

Пішковці Анна-Марія Михайлівна - асистент кафедри громадського здоров'я та гуманітарних дисциплін ДВНЗ «Ужгородський національний університет»; м. Ужгород, вул. Університетська 14.

annamariaremez@gmail.com. 